\title{
Catering to Organizational Needs in Ethics Management: The Case of the European Commission
}

Citation for published version (APA):

Nastase, A. (2014). Catering to Organizational Needs in Ethics Management: The Case of the European Commission. International Journal of Public Administration, 37(2), 93-105.

https://doi.org/10.1080/01900692.2013.836668

Document status and date:

Published: 01/01/2014

DOI:

10.1080/01900692.2013.836668

Document Version:

Publisher's PDF, also known as Version of record

Document license:

Taverne

\section{Please check the document version of this publication:}

- A submitted manuscript is the version of the article upon submission and before peer-review. There can be important differences between the submitted version and the official published version of record.

People interested in the research are advised to contact the author for the final version of the publication, or visit the DOI to the publisher's website.

- The final author version and the galley proof are versions of the publication after peer review.

- The final published version features the final layout of the paper including the volume, issue and page numbers.

Link to publication

\footnotetext{
General rights Owners
rights.

- You may freely distribute the URL identifying the publication in the public portal. please follow below link for the End User Agreement:

www.umlib.nl/taverne-license

Take down policy

If you believe that this document breaches copyright please contact us at:

repository@maastrichtuniversity.nl

providing details and we will investigate your claim.
}

Copyright and moral rights for the publications made accessible in the public portal are retained by the authors and/or other copyright owners and it is a condition of accessing publications that users recognise and abide by the legal requirements associated with these

- Users may download and print one copy of any publication from the public portal for the purpose of private study or research.

- You may not further distribute the material or use it for any profit-making activity or commercial gain

If the publication is distributed under the terms of Article $25 \mathrm{fa}$ of the Dutch Copyright Act, indicated by the "Taverne" license above, 


\section{Catering to Organizational Needs in Ethics Management: The Case of the European Commission}

\section{Andreea Năstase}

To cite this article: Andreea Năstase (2014) Catering to Organizational Needs in Ethics Management: The Case of the European Commission, International Journal of Public Administration, 37:2, 93-105, DOI: 10.1080/01900692.2013.836668

To link to this article: https://doi.org/10.1080/01900692.2013.836668

\section{曲 Published online: 14 Jan 2014.}

Submit your article to this journal $\llbracket$

Џll Article views: 280

Q View related articles $\longleftarrow$

View Crossmark data $\nearrow$

Citing articles: 1 View citing articles 


\title{
Catering to Organizational Needs in Ethics Management: The Case of the European Commission
}

\author{
Andreea Năstase \\ Faculty of Arts and Social Sciences, Maastricht University, Maastricht, The Netherlands
}

\begin{abstract}
This article examines the ethical challenges encountered by European Commission officials in their day-to-day work. Based on an intra-organizational comparison between three Directorate Generals (DGs), the analysis reveals that ethical questions differ in these settings, depending on the type of external actors employees engage with. This internal heterogeneity makes the European Commission an interesting (unusual) case, which highlights the challenges of practising ethics management in a way that is truly responsive to organizational needs. The policy solution implemented by the Commission as a response-the appointment of "ethics correspondents" at DG level—has been only moderately successful.
\end{abstract}

Keywords: ethics, ethics management, European Commission, administrative reform

\section{INTRODUCTION}

In the past two decades there has been a growing alarm among practitioners and academics alike over the decline of behavioral standards in public life. In this context, ethics (which is used here to refer exclusively to appropriate behavior in public office) has become the target of an impressive amount of regulation. Ethics management-understood as "a systematic and conscious effort to promote organizational integrity" (Menzel, 2005, p. 29)—currently represents a best practice standard, and has led to a mushrooming of codes of conduct, ethics trainings, specialized counseling, and other similar instruments, within public and business organizations alike. At the root of this trend is a conviction that ethics can, and should be managed "in the same breath and manner in which we talk about managing budgets, policies, or people" (Menzel, 2001, p. 355).

Consequently, a great deal of empirical research on public administration ethics deals with mapping the policy instruments and approaches employed in ethics management. Large surveys have been conducted to this end (for instance, Bossaert \& Demmke, 2005; OECD, 2000), as well as comparative work on smaller scale (e.g., Behnke, 2002; Palidauskaite, 2005; Palidauskaite, Pevkur, \& Reinholde,

Correspondence should be addressed to Andreea Năstase, Faculty of Arts and Social Sciences, Maastricht University, Grote Gracht 90-92, Maastricht, The Netherlands. E-mail: a.nastase@ maastrichtuniversity.nl
2010; Smith, 2004). Research efforts have also gone into understanding the impact of these regulatory interventions, although here contributions have often had a limited focus. One illustrative example is Menzel's (2005) literature review, which largely covers studies that are focused on isolated policy instruments, e.g., municipal audit committees (West \& Berman, 2003), ethics trainings (West \& Berman, 2004), and ethics officers (Smith, 2003). In a nutshell, research seems primarily geared toward enhancing our knowledge over what ethics management is, and (partially) how it works.

Against this background, conspicuously little is known in public administration about the way ethics itself (as opposed to ethics policy) materializes in different organizational settings, and, related to this, how it is experienced and perceived by officials working in those settings. To be clear, the gap is primarily empirical, as there is a wealth of normative work which deals with the content of ethical obligations and ethical contradictions in the public service (Bowman, 1991; Cooper, 1998; Denhardt, 1988; Laverty, 1989 to name but a few). Furthermore, empirical research has not neglected questions of how individuals make ethically relevant decisions, and what influences them-on the contrary, there is a large body of work, generally rooted in a psychological perspective (following the pioneering work of Kohlberg (1969, 1981) and Rest (1986)), which deals with this. However, the research effort is geared toward developing and testing general models of ethical decision-making (see reviews 
by Ford \& Richardson, 1994; Loe, Ferrell, \& Mansfield, 2000; O'Fallon \& Butterfield, 2005; Wittmer, 2001, 2005)_consequently missing out on the specific (organizational) context of ethics, and the specific understandings of those who make decisions with an ethical content. Contributions (particularly qualitative work) which do touch on these issues tend to be the exception, rather than the rule (for instance, Morgan and Kaas's (1993) study on the "ethical crisis of role reversal" experienced by senior public managers, De Graaf's (2011) exploration on the loyalties of top public administrators, and Lupson and Partington's (2011) contribution on civil servants' different conceptions of accountability).

And yet, this question of "situational ethics" is crucial. Ethics represents a lofty philosophical construct, whose relevance will remain obscure unless one understands how it materializes in specific organizational and work contexts. As Frederickson and Walling (2001, p. 37) remark, "ethics is abstract, while the practices of administration are irremediably concrete." These aspects are all the more relevant considering the frequent recommendation that ethics policies ought to be tailored to the specificity of organizations, as well as their broader political and social context (see OECD, 1996, 2009).

This article targets the lacuna described above by presenting a selective, but significant portrayal of the ethics environment of the European Commission. Specifically, the analysis aims to identify and explore the ethical challenges encountered by European civil servants in their day-to-day work. Based on this exercise, the article further explores whether, and how ethics policy interventions have responded to the specificities of the organization.

Owing to its unusual organizational characteristics, the European Commission represents an interesting case study for the research gap identified above. Placed "at the heart" (Nugent, 1997, p. 6) of a system of governance largely considered to be sui generis, ${ }^{1}$ the Commission performs a mix of institutional roles which are exceptional for an international body, and which, in a national context, would be distributed between different institutions. Namely, the Commission simultaneously has responsibilities in the initiation, execution, and enforcement of European Union (EU) policy - three functions which, as the following section will show, are not only quite substantial, but also very different from each other. The article takes this functional diversity as a starting point, as it maps ethical questions and dilemmas associated to each of the Commission's institutional roles, and seeks to establish whether significant differences exist between them.

\footnotetext{
${ }^{1}$ As evidenced by celebrated definitions of the European Union, such as "less than a federation, more than a regime" (Wallace, 1983, p. 403), "neither a state, nor an international organization" (Sbargia, 1992, p. 257) or "the middle ground between the cooperation of existing nations and the breaking of a new one" (Scharpf, 1988, p. 242).
}

A differentiation of the ethics environment of the Commission along functional lines is not far-fetched. Like any large bureaucracy, it is prone to fragmentation: previous studies have found that the main organizational units, the Directorate Generals (DGs), have a tendency to develop their own distinct work-styles and administrative subcultures (see, for example, Christiansen, 1997; Cini, 1997; SchönQuinlivan, 2008). Moreover, the identity of the DGs is "closely allied" with their functional responsibilities (Cini, 1997). This has caused the Commission to be characterized as a "multi-organization" (Cram, 1994). Equally important, there are empirical arguments in support of this possibility. After all, the main criticisms received by the Commission over ethical standards do apply to some of its activities more than others. For instance, the propriety of exchanges with lobbyists is relevant mainly for the policy initiation function, while questions of financial irregularities and fraud (which have also proved to be a hot spot) pertain mainly to the Commission's executive role. In conclusion, it is possible that officials working in different parts of the organization do not get exposed to quite the same problems. If this is true, the Commission represents a case that highlights the practical challenges of doing ethics management in a way that truly responds to organizational needs.

The article deals only with the administrative echelons of the Commission, leaving aside the political staff (i.e., the Commissioners and their cabinets). Furthermore, within the services, only the operational DGs are targeted, i.e., the ones which are actively involved in policy-making within a specific issue area (e.g., DG Competition, DG Agriculture, DG Health and Consumers, DG Environment). The administrative DGs, which have internal managerial tasks, or interservice coordinating functions (e.g., the Secretariat General, DG Budget, DG Human Resources, DG Translation) are left aside because, unlike the first category, they do not exhibit the entire range of ethics challenges confronting the Commission. As a rule, the activity of administrative DGs does not impact directly on Member States, or on societal interests (through regulation, distribution of funds, etc.).

The article is structured as follows. The first part presents the organizational profile of the European Commission, and a brief overview of the content and evolution of its ethics management system. The second part explains the choices made in terms of research design and methodology, and outlines the limitations of the study. The third (and largest) section will present an empirically informed description of how officials perceive their activity in the Commission, and the ethical questions connected to it. The analysis will highlight the differences and similarities between DGs, and offer a tentative explanation for the observed patterns. The last section of the article relates these findings to the practice of ethics management, by discussing the relevant elements of the Commission's internal ethics policy. Conclusions will follow. 


\section{THE EUROPEAN COMMISSION: ORGANIZATIONAL CHARACTERISTICS AND ETHICS MANAGEMENT}

The following pages serve as a quick guide to the complex organization that is the European Commission, thus providing the context for the analysis undertook in this article. The section introduces the Commission's place and functions in the EU institutional system, and, related to that, the specific ethical risks faced by its employees. It also offers a brief overview over the development of the organizational ethics management system, and the ethics-relevant regulations which apply to Commission officials.

\section{Institutional Functions and Ethical Risks}

Commonly dubbed as the motor of European integration, the European Commission is one of the most powerful international executives in the world. Its attributions are significantly larger than it is generally the case for an international secretariat, but less substantial than those of a national government. As already stated, the Commission fulfills three core functions in the EU institutional system, namely the initiation, execution, and enforcement of policy. ${ }^{2}$

To begin, the Commission is the place where most EUlevel policy initiatives are developed. This pivotal position is due to its exclusive right to draft legislative proposals, although in doing so it often acts on the request of other European institutions (particularly the Council). The EU political system, encompassing a wide variety of actors with different interests and views, encourages the pre-cooking of decisions before entering the formal stages of decisionmaking. This leads the Commission, when acting as policy initiator, to engage in a lot of informal activity, from floating ideas and advocacy work, to checking the pulse in other EU institutions and inter-institutional committees, and promoting dialogue with societal interests.

Second, as policy executor, the Commission is mostly responsible for the coordination and supervision of frontline implementation in the Member States. This implies several different aspects. First, the Commission produces implementing legislation (generally in the form of regulations and decisions), and issues a large number of guides and codes, explaining in detail the application of particular rules. Second, financial management is part of the Commission's

\footnotetext{
${ }^{2}$ The EU literature generally lists five or six functions of the Commission-e.g., Nugent (2001) enumerates policy initiation, legislative functions, executive functions, legal guardianship, external representation, mediation and brokerage of interests, and mobilization of policy support. There is, however, significant overlap between those functions to justify a more crisp approach (for example, policy initiation implies a legislative exercise, as well as consensus-building, brokering between opposed interests, etc.). Admittedly, the classification used here neglects the attributions of external representation, although there are reasons to consider them part of the Commission's managerial/executive role (Cini, 1996, p. 25).
}

executive role. The Commission oversees the collection of EU budgetary revenue, prepares the EU budget, and manages expenditure. The majority of EU funds are spent under shared management ( $76 \%$ of funds), a system where budget implementation is delegated to the Member States, with the Commission retaining a supervisory and audit role).

Finally, the Commission also acts as "guardian of the Treaties," ensuring that EU law is implemented and respected at national level. When checking implementation, it relies primarily on a notification system which requires Member States to report to Brussels steps taken to adapt their national legislation to EU law. Breaches are dealt with through the infringement procedure, where the Commission has the power to initiate legal action against Member States, should they fail to comply with EU law. The European Court of Justice decides on the cases.

In conclusion, the European Commission affects the lives of millions of citizens, in very tangible and concrete ways. In fact, one would be hard-pressed to think of policy actors (be they public authorities, business interests, or third sector organizations, in the EU or outside of it) which would not hold a stake in what the Commission does. Consequently (and perhaps not surprisingly) maintaining independence has proven an ethically sensitive point. For instance, the relationship with the lobby is a thorny issue, especially so in recent years, when the population of interest representatives in Brussels (and the scope of European policy) have expanded tremendously. It is illustrative that the Alliance for Lobbying Transparency and Ethics Regulation (ALTEREU), the principal watchdog coalition in Brussels, has been formed around a shared concern over the capture of EU agenda by powerful corporate lobbies. Sleaze stories which featured EU officials engaging in shady, back-door deals with lobbyists (for instance, the case of Fritz-Harald Weing in $2008^{3}$ ) added fuel to the fire.

Another threat to the Commission's independence, especially considering its position as the supranational institution par excellence, is the (sometimes aggressive) political influence of EU Member States. Although this is mostly visible at the political level-all Commissioners walk a fine line between being sensitive to their country's national interests and advocating them too blatantly (Spence, 2006) — the problem is present in the administrative services as well. In the past, the influence of Member States has materialized in a number of controversial practices, such as the national "flagging of posts," the informal system of "national quotas," and the bypassing of regular recruitment procedures through

\footnotetext{
${ }^{3}$ The Sunday Times broke the story concerning Fritz-Harald Weing, a former Director of the Trade Defense in DG TRADE, who had leaked highly sensitive, confidential information to two undercover journalists, posing as lobbyists for a Chinese company. Moreover, he had done so over lavish dinners at Brussels' elite restaurants, and apparently with the promise of a financial reward of $€ 100,000$ waiting in a frozen bank account, which Weing would have been able to access after retirement.
} 
"parachuting" former cabinet members to permanent posts in the services (Coombes, 1970; Page, 1997; Spence \& Stevens, 2006; Stevens \& Stevens, 2001).

Finally, financial matters also represent a hot spot. The reports of the Committee of Independent Experts (CIE) in 1999, which were commissioned by the European Parliament and eventually lead to the block resignation of Santer Commission (see below), have documented procedural problems with calls and awards of contracts, and signaled out the weakness of financial management systems. Later on, in 2003, the so-called "Eurostat affair" revolved around the manipulation of tender procedures and the siphoning off of funds by high-ranking employees of EU's statistical office. Arguably, the Commission is in a better shape today due to intensive reforms in this area; however, the funds under shared management are still plagued by irregularities. This has represented probably the single most important reason why, for many years, the Commission has failed to obtain a clean bill of health in the annual audit reports of the European Court of Auditors.

\section{Ethics Reforms}

With the end of the so-called "permissive consensus" on European integration in the 1990s, the democratic quality and legitimacy of the EU political system have come under fire. As an unelected, remote bureaucracy, with far-reaching (and ever-growing) powers, the European Commission could not afford to neglect these questions, and, consequently, ethics has become a particularly salient topic. It was propelled to the forefront of the reform agenda by the resignation of the Santer Commission in March 1999, which probably represented the gravest public scandal in the history of the organization. The resignation followed the very public and painful embarrassment of the Commission over two investigation reports commissioned by the European Parliament (i.e., the CIE reports), which revealed evidence of mismanagement, fraud, and nepotism (for more on the Santer resignation, see Cini, 2007; Judge \& Earnshaw, 2002; MacMullen, 1999).

In the aftermath of this crisis, an overhauling program of administrative reform was outlined in the form of the White Paper on Reforming the Commission (2000). Also called the Kinnock reforms (in reference to Neil Kinnock, the Commissioner responsible at the time for administrative affairs), this package was implemented over the term in office of the Prodi Commission, and it laid the foundations of the Commission's ethics management system. Some of the most significant measures were: amending the Staff Regulations, establishing the investigation, and Disciplinary Office of the Commission (IDOC), introducing the Code of Good Administrative Behaviour, and the significant changes to the human resources, as well as financial control and audit systems. Some of the HR reforms (the obligatory mobility for senior managers and "sensitive" posts, increasing national diversity in the composition of cabinets, among others) were meant to counteract the nefarious influence exercised by national governments within the European civil service. In financial matters, the reforms aimed to close loopholes signaled out in the CIE reports (by separating the internal control and internal audit functions, and decentralizing to DG level expenditure authorization and control).

The administrative reform agenda continued during the Barosso I Commission with the well-publicized European Transparency Initiative (2006), which, alongside measures to boost transparency in financial management and interest group activity ${ }^{4}$ also addressed internal ethical standards. This was accomplished through the Communication for Enhancing the Environment for Professional Ethics in the Commission (2008), ${ }^{5}$ which sought, on the one hand, to tie the loose ends of the Kinnock reforms (specifically, by streamlining regulations on favors, gifts, and hospitality, and simplifying authorization procedures), and, on the other, to increase ethics guidance and awareness-raising throughout the Commission (Năstase, 2012). In this package, one measure in particular stands out - the appointment, within each DG, of an "ethics correspondent," i.e., a person who would serve as a point of contact for all ethics-related issues, with strictly advisory attributions. This has significantly increased the Commission's ethics bureaucracy, ${ }^{6}$ and made possible the flurry of internal ethics guidance activities, at all levels, which followed after 2008. The current Commissioner for Inter-Institutional Relations and Administration, Maroš Šefčovič, has largely followed the ethics agenda set by his predecessor.

In conclusion, after over a decade of reforms (briefly outlined above), the Commission nowadays possesses a well-developed policy arsenal for managing ethics, which is, by-and-large, typical and in line with international best practice. ${ }^{7}$ With a few exceptions, the ethical standards which apply to European civil servants, and the control and compliance framework built around them, are no different than what is generally found in the public administration systems of EU Member States.

Ethical standards are laid out in Title 2 of the Staff Regulations, which opens, significantly, by instructing

\footnotetext{
${ }^{4}$ The European Transparency Initiative established a website which publishes the end beneficiaries of EU funds (grants), as well as a voluntary registration system - the so-called Transparency Register - for interest representatives who access the Commission (and, more recently, the European Parliament).

${ }^{5}$ Henceforth referred to as the Ethics Communication

${ }^{6} \mathrm{Up}$ to 2008 , the internal ethics bureaucracy by-and-large included DG Human Resources (particularly IDOC), a specialized unit in the Secretariat General, and (partially) the internal control and audit.

${ }^{7}$ A survey by Bossaert and Demmke (2005), which included all (then 25) Member States, as well as the European Commission, demonstrates that the Commission's policy instruments inventory is fairly similar to that of most national public administrations in the EU.
} 
officials to carry out their duties "solely with the interests of the Communities in mind" (Art. 11). This requirement mirrors the Commission's role as defined in the Treaties, namely the promoter of the European interest as a whole. A good number of provisions deal, in one form or another, with conflict of interests. Officials are prevented from dealing with any matter where they have "any personal interest such as to impair their independence and, in particular, family and financial interests" (Art. 11a), and they (and their spouses) are also required to declare interests. An obligation to ask for authorization applies for undertaking work assignments (paid or not) outside their main employment (Art. 12(b)), receiving gifts, honors, and hospitality (Art. 11), running for public office (Art. 15), or publishing works related to the activity of the Communities (Art. 17a). Furthermore, postemployment restrictions are in place, with the Commission being entitled to forbid any work performed by an ex-official within two years of leaving its service, should it be judged to conflict with "the legitimate interests of the institution" (Art. 16). Another salient issue is officials' duty of confidentiality, which prevents them from disclosing information received in the line of duty, unless that information is already public, or accessible to the public (Art. 17). Particularly significant is Art. 22, which makes staff members financially liable for losses suffered by the Communities as a result of their "serious misconduct." Finally, Art. 22a and 22b deal with whistle-blowing, by defining a framework for making disclosures, as well as protection measures.

Within the Commission, the main body tasked with enforcing ethical standards is IDOC, which conducts disciplinary investigations and imposes sanctions. This work is complemented by the internal audit service-internal control standards stipulate that "management and staff are aware of and share appropriate ethical and organizational values and uphold these though their own behavior and decision-making" (Commission, 2007, p. 16). Outside the Commission, the European Ombudsman investigates complaints about maladministration. The European Court of Auditors is EU's independent external audit body. The European Anti-Fraud Office (OLAF) handles cases involving harm to the Community's financial interests, and serious breach of professional obligations. Although OLAF is a powerful investigative body, its attributions are nevertheless limited-in the absence of an EU-level prosecution body, criminal offences are dealt with by authorities in officials' countries of origin.

In conclusion, the system of ethics management at the European Commission does not seem unusual-neither in its content, nor in its scandal-induced development path. However, the organization is unique in many ways. This raises the possibility (which is empirically investigated in the rest of this article) that there might be something "special" about ethics at the Commission, that has more to do with the nature of the organization itself, rather than its ethics policy framework.

\section{RESEARCH DESIGN AND METHODOLOGY}

The article relies on qualitative research methods, specifically on document analysis and semi-structured interviews with European Commission officials. The purpose of the document analysis was to map the content of the Commission's ethics policy, and the internal administrative practice which characterized its implementation. It covered official strategic documents (white and green papers, communications, etc.), as well as internal texts obtained during fieldwork (codes of conducts, administrative guides, training manuals, flyers, etc.). Two categories of participants were interviewed-on the one hand, 25 officials who were part of the Commission's ethics bureaucracy, and, on the other, 18 "regular" officials (not ethics experts), who were working for the organization in various other capacities. Officials in the first category were targeted because of their first-hand knowledge regarding the development, implementation, and context of ethics reforms in the Commission. Some of them were responsible for the overall coordination of ethics policy - the majority, however, had their attributions limited to a specific DG (this latter group were the so-called "ethics correspondents" $)$. Officials in the second category, who were selected based on their DG affiliation, offered a view of ethics "from the work-floor," that is the experience and perception of those involved in day-to-day work at the European Commission.

Because of the sensitivity of the subject, all interviews were confidential—consequently, in what follows, names will be replaced with randomly assigned numbers. Interviewees in the first category will be referred to with the term "ethics official" (to denote their expertise in the area of ethics), while those in the second will be referred to as "officials." Furthermore, in some quotes the interviewees' nationality will be obscured. The analysis will not go into specifics on the activities of the units where participants were located, lest they should become easily identifiable within their respective DGs. Most interviews were taped and transcribed (in the few instances where this was not possible, extensive reports were prepared soon after interviews were concluded). The transcripts and reports were analyzed with specialized software (ATLASti), which made it possible to code the material, and discover the recurring patterns and topics in the data.

The "regular" officials were selected from three DGs of the European Commission (i.e., DG Internal Market, DG Regional Policy, and DG Environment ${ }^{9}$ ), deemed to be

\footnotetext{
${ }^{8}$ For this category, a total of 17 DGs were surveyed. Out of these, 14 were "operational", and 3 were "administrative. Thus, the collected information can be considered representative for a wide range of activities and functions performed in the Commission.

${ }^{9}$ Henceforth, the DGs will be referred to with the abbreviations used within the Commission, namely DG MARKT, DG REGIO, DG ENV, and DG COMP, respectively.
} 
TABLE 1

Selected DGs

\begin{tabular}{|c|c|c|c|}
\hline Commission function & Selected DG & Reason for selection & Interviews \\
\hline Policy initiation & DG Internal Market (MARKT) & $\begin{array}{l}\text { DG MARKT is active in one of the oldest (and most heavily } \\
\text { lobbied) policy areas under Community competence. }\end{array}$ & 6 interviews in 2 units \\
\hline Policy execution & DG Regional Policy (REGIO) & $\begin{array}{l}\text { DG REGIO manages spending for regional policy, which } \\
\text { traditionally has been the second largest spending area of } \\
\text { the EU budget, after agriculture and rural development. }^{\text {a }} \\
\text { This is also the area where the specifically EU mode of } \\
\text { shared management is used. }\end{array}$ & 7 interviews in 2 units \\
\hline Policy enforcement & DG Environment (ENV) & $\begin{array}{l}\text { DG ENV is active in the one area of the acquis } \\
\text { communautaire which is generating the most significant } \\
\text { case load of the Commission, both in terms of open cases } \\
\text { under investigation, and in terms of infringement cases. }{ }^{\text {b }}\end{array}$ & 5 interviews in 1 unit \\
\hline
\end{tabular}

Notes: ${ }^{a}$ Agriculture and rural development make up $43 \%$ of EU budget expenditure, while regional policy represents $27.7 \%$. For more in this see: http:// ec.europa.eu/budget/figures/fin_fwk0713/fwk0713_en.cfm\#cf07_13.

${ }^{\mathrm{b}}$ On average, $20 \%$ of Commission infringement actions are handled by the DG ENV. For more on this, see: http://ec.europa.eu/environment/legal/law/ statistics.htm.

representative for its institutional functions. Table 1 details the reasons behind the case selection.

It is important to point out that most of the Commission's operational DGs generally perform all three institutional functions (i.e., they contain administrative units, or perhaps entire directorates, dedicated to policy initiation, execution, and enforcement, respectively). Thus, it would be incorrect to speak of "pure" executive, or enforcement DGs, but of DGs which exercise these functions in different proportions. For instance, some are big spenders (e.g., DG AGRI, DG REGIO, DG EMPL), while others are more involved in policy-making (e.g., DG MARKT, DG TAXUD, DG INFSO). So, it is in this sense-i.e., the predominance of a specific function-that representativeness of the selected DGs is to be understood.

Furthermore, a decision was made to focus the analysis on just a few administrative units within each DG. The administrative unit is the smallest organizational component of the Commission-essentially, a team of officials (containing on average 20 members), who work on specific tasks. To be clear, in each DG I interviewed participants who belonged to the same administrative unit, or to units which were working closely together. In this way, it was possible to capture how ethics is materialized in various parts of the Commission, in very specific work contexts. The selected units fulfilled the function for which their DG was selected (i.e., a policy initiation unit in DG MARKT, a policy execution unit in DG REGIO, etc.).

Before moving on, a few words regarding the limitations of this study are in order. First, this represents an exploratory study, tackling as it does aspects which have not been previously touched in the literature. To be clear, the small body of research on ethics in the European Commission (Cini, 2004, 2007, 2008, 2010, 2013; Dercks, 2001; Giusta, 2006; Hine \& McMahon, 2004; Năstase, 2012) is entirely dedicated to the analysis of policy responses. The more substantial literature on Commission socialization, roles, and identities (e.g., Abélès, Bellier, \& McDonald, 1993; Hooghe, 2001, 2012; Shore, 2000) touches on ethics only marginally, or not at all. In this context, the article breaks new ground. Its findings are by no means definitive, but rather represent useful pointers for future research.

Second (and related), being an entirely qualitative project, this piece cannot claim representativeness in the same terms as a statistical work would. That said, the sample allows for findings to be extrapolated if not to the entire organization, than to significant parts of it. As explained above, the "regular" officials were recruited from DGs deemed representative of the most important institutional functions of the European Commission. Furthermore, the composition of this group was heterogeneous with regard to nationality, gender, age, length of service, and (to some extent) type of employment contract, all of which are factors that may influence individuals' views toward ethics in office.

\section{THREE SNAPSHOTS OF ETHICS IN DAY-TO-DAY WORK AT THE EUROPEAN COMMISSION}

This section represents an account of how officials perceive their day-to-day activity in the Commission, and the ethical questions connected to it. The purpose is to offer a subjective portrayal of ethics at the Commission, as it is experienced directly by the people who work in this organization. Rather than full-blown comparisons, what the following pages present are three parallel snapshots of ethics is daily work practice.

\section{DG Internal Market}

As policy-makers, the basic reality structuring the work of officials in DG MARKT is, as one interviewee explains, 
that the Commission produces regulation which should be implemented by others:

The difficulty we face here is that the Commission is not structured to deliver that sort of work, it's structured to build regulation, policy, strategy towards something, but not to actually do that. That's not true entirely of the Commission, but it's true of DG MARKT. (Official \#11)

This problem is compounded by the scope of EU policy, namely the many levels of political and administrative authority, and the multitude of interests which it needs to accommodate. This means that MARKT officials operate in a very political environment, which requires that they be able to navigate a complex constellation of actors in order to find a policy solution which is acceptable to most. In this exercise, they see the Commission as reliant on the cooperation of other actors, which translates into a certain amount of vulnerability in their self-perception:

We rely a great deal on information that comes our way. When you're making policy, it's important to have access to as many angles as you possibly can, to be aware of the issues, or threats, or risks that might affect you. (Official \#11)

The job becomes very difficult when the stakeholders are in an adversarial relationship with each other. As one interviewee explains with regard to the project on which she works:

[I]n this area there's a lot of money involved, and the positions have become very ... entrenched, and there's very little flexibility on both sides to see the other people's point, and to look for some common way of dealing with the issues. (Official \#7)

In light of this, it is unsurprising that MARKT officials believe the value of their stakeholders is given not only by the information they can provide, but also by their flexibility, and openness for compromise. For example, this is how one official describes a good lobbyist:

The good lobbyists are really those who come with facts, who come with good economic arguments, and obviously who are ready to think about alternatives, they are not all for just one possible solution, and who are ready to accept compromises, because they understand that there are a number of different stakeholders. (Official \#23)

In their relationship with external stakeholders, MARKT officials experience a number of challenges and problems, all of which have clear implications from an ethics viewpoint. To begin with, there is the traditional tension between inclusiveness and efficiency of decision-making. In the dense web of interests surrounding the EU institutions, it can be exceedingly difficult to get all relevant stakeholders involved in discussions (and to decide who is relevant in the first place), irrespective of how much good will the Commission might have. In this sense, reflecting on the toughest parts of her job, a MARKT policy officer declared:

... what we found there quite difficult is to identify criteria according to which we might invite these groups - there are so many of them around, we cannot say: 'OK, whoever is interested, participate', then we would have hundreds of people there, so we somehow have to select. (Official \#7)

Another problem is the (sometimes sharp) inequality of resources between different camps of stakeholders. From an ethics perspective, this rings alarm bells in terms of impartiality and equal treatment, as officials will inevitably get more exposure to the party which is better at organizing and lobbying in the EU arena. One official offers a good description of the difficulties faced:

Initially it was easier to deal ... it's always easier to deal with the [A] side, because they are very well set up, they have their representative organizations, for music, film, software etc.

\section{So you know whom to go to.}

Exactly. And they are representative and can make decisions. So, in the [B] side it's rather more difficult, because they don't all join the same representative organizations, so you might have a leisurewear organization, a tobacco organization, so that brings the number of businesses down to a level that you can negotiate properly, but it's still a huge range of sectors. So initially as well, the $[\mathrm{A}]$ have put together more detailed reports of the problems they face, and have worked together on those, so again, that was at our disposal. And I would say, if I had to, that in the past they've been far more adept at lobbying, far more adept at placing their situation to key political decision-makers, whereas on the other side, [B] have probably been less organized. (Official \#11)

Finally, it is important to note that, in time, familiarity builds up. Despite the high numbers and diversity of potential stakeholders, MARKT officials report a dynamics of selfselection. As the process moves forward, there are only a handful of stakeholders which remain continuously involved, and quite naturally a closer relationship would ensue with them:

It's always the same people that you deal with, so most people are known either to yourself, or to someone else in your unit, or to someone else in the Directorate, so although it's a large circle, it's still a circle that you oversee, so it would be rare that someone comes there that you've never seen or heard of. (Official \#7) 


\section{DG Regional Policy}

The two units in DG REGIO where interviews were carried out were country operational desks, each of them managing the relationship with one Member State. Their respective countries were both new Member States (post-2004 enlargements), which had significant problems in absorbing EU funds. On the one hand, the country desks are responsible for supporting national authorities in formulating and implementing programs funded through EU money. At the same time, however, they monitor the execution of those programs, with the power to stop payments and impose corrections in the event of serious irregularities. Work in DG REGIO is guided by attempts to strike the right balance between this kind of positive and negative incentives. In many ways, in the discourse of REGIO officials the relationship between the Commission and the Member State is portrayed as a connection between teacher and students.

On the one hand, REGIO officials feel that it is their duty to support the national authorities in producing value for European money. Although the Commission can't deliver on their behalf, it can push the national authorities in the right direction-sometimes to such a large extent that it might overstep the limits of its formal mandate. For example, this is how one official describes his tendency to micro-manage, worrying that he might be overdoing it:

We push them, but we should not do that, it is not our job as DG REGIO, I mean we do it because-again-we are not here just to distribute money, but to spend money with sustainable effects on development. [ . . . ] But we cannot deliver reforms on their behalf, so we cannot do more than putting it on their agenda, and sometimes that's really even crazy, I mean we meet even secretaries of state and ministers, and they ask us: 'what do I have to do?', and sometimes you have to take the pen and even write the initiatives for them, for the action plan - which is not ... it's a matter of ownership, they will say: 'the Commission asked us to do'. (Official \#34)

Behind this tendency to overdo it is a general sense of frustration, among REGIO officials, with the weak governance, and the lack of political and administrative capacities in the countries under their custody. This is how one official describes the situation, in a rather emotional tone, which is by no means uncommon among his colleagues:

[Y] ou have said or done the same many times with this country, and you are fed up that they never learn, or you're talking to the wall, because they move, new people come, new politicians, they have elections, and half of them go, and then you have to say the same again, they do the same mistakes. (Official \#30)

On the other hand, however, REGIO officials are also responsible to monitor compliance with the rules and conditions attached to EU funding. The Commission steps in only when there is evidence of major irregularities, and/or general weakness in the Member States' control systems, and it can either apply a financial correction, or interrupt, or formally suspend payments to the program concerned. The interviews have shown that these powers are used only as a measure of last resort, with lots of effort being spent instead on averting irregularities before reaching the point of no return. However, as one official points out, in taking preventive action, the Commission puts itself in "a sort of extended interpretation of shared management" (Official \# 18). To give one example, one of the units, acting of reports in the press, decided to conduct a desk review for a call of projects worth several hundred million euro. They concluded that the selected projects were severely flawed, and consequently put pressure on the national authorities to cancel the call before signing off on the contracts. However:

that was a big risk for us, because we could be accused, under the principle of shared management, of interfering in Member State business, many other desks would have set some distance - 'these are not projects we have to assess, the Member State knows best, they know what they're doing'. (Official \#18)

This kind of risky preventive intervention proves that, for REGIO officials, the split responsibility inherent in the system of shared financial management is throwing up ethical questions. It seems that at least some of them feel the ultimate responsibility rests with the Commission, which justifies approaches that are more hands-on and controversial. One interviewee has put this in very clear terms:

I'm totally aware that if we do not ensure that money is well spent, nobody else has a true incentive to do that. We give the money from the European taxpayers to the states. And for the states it means this is free money, [ . . . ] and you can say out of sheer psychology, normal economic behaviour, [that] you'll never feel you are as responsible with other people's money as you do with your own. (Official \#18)

The situation is additionally complicated by the fact that the relationship with national authorities is a very close oneREGIO officials report having contact (by phone, email, etc.) almost daily, while country visits occur approximately once every two months. From an ethics perspective, this frequent (and sometimes informal) contact bears the risk that desk officers will lose impartiality and objectivity:

Of course they want to treat you nicely - not only because they are nice people, and they are human, but, in my opinion, also because they want to be nice to the official who can take a bad decision against them, if they omit, forget a document, or they make some irregularity, and then you say: 'this is irregular, we don't pay the expenditure' $[\ldots$. . This is considered a sensitive post; you can have too close relations, you 
can feel bad [for them], or sometimes the opposite - you can feel too tough. (Official \#30)

\section{DG Environment}

The Commission's relationship to Member States in this area may be described as "enforcement by negotiation," because litigation is seen as a measure of last resort. In fact, the infringement procedure is designed so as to offer Member States multiple opportunities to fall in line before reaching the court (with mileposts such as the reasoned opinion, and the letter of formal notice). ${ }^{10}$

The Commission is in a rather vulnerable position, as it relies enormously on the information fed to it by complainants, and on Member States' responses. An aspect of this problem, which is particularly relevant for DG ENV, is the lack of resources for gathering and analyzing technical data. EU environmental policy is characterized by large amounts of very technical and diverse legislation. The case handlers rely on the expertise offered by the scientific units in DG ENV, but that can often be insufficient. The shortage of technical knowledge was one of the most oft-mentioned problems in the interviews. One official described how such insufficiencies (especially when compared to the resources of the other party) are by themselves enough to lose the case for the Commission:

It took me 10 years, and it was a case I took over when I got started, and we got the judgement last year, and we lost on every single ground. And it was incredibly frustrating, because I think, in hindsight, the case was far too technical, and became gradually far too technical, beyond my capabilities to deal with. [ . . . ] The case started off OK, but as we got into the court proceedings, it was obvious that the [COUNTRY] had a whole big team working on it, and we were just completely out-manned, outnumbered, and I found myself working week-ends, evenings, unreasonable times on this case, and investing a lot of effort. (Official \#9)

Ethical challenges revolve around the relationship with Member States. The work is organized in such a way that

\footnotetext{
${ }^{10}$ The infringement procedure has two phases. In the first one (nonlitigation phase), the Commission examines the facts of a case, and engages in further investigation by contacting the authorities of the Member State, possibly also the complainant(s). If it decides there is a case, the Commission opens the infringement, by sending the letter of formal notice, and inviting the Member State to submit its observations by a specified date. If it is not satisfied, the Commission will proceed further by sending the reasoned opinion, where it states the reasons why it considers that there has been an infringement of EU law, and calls on the Member State to comply with EU law by a specified date. If this step fails as well, the Commission enters the second phase of the infringement procedure (the litigation phase), where it refers the case to the European Court of Justice (ECJ). The purpose of the infringement proceedings is to determine the Member State to comply with EU law before referring the case to ECJ, and most cases can be solved in this way.
}

case handlers end up dealing with the same Member State for long periods of time. In order to encourage compliance and find pragmatic solutions before cases reach court, the working relationship needs to be a good one-sometimes, perhaps, too close:

Here, the ethical danger might be that you get too close to your Member State. That is the danger in this job [ . . . ] you do build up relationships with people on the other side, there are some people you know that are good, and whom you would talk to, who would also try to find pragmatic solutions. You need the personal contact with people, but you also need to keep a certain distance. (Official \#9)

What is more, case handlers are usually nationals of the Member State they oversee. The interviews have revealed that the main reason for this arrangement is efficiencyunderstanding the language, the legal framework, and the culture of a country are key advantages for a speedier process, and better interaction. However, this arrangement does create a potential for conflicting loyalties (or might be perceived to do so), and therefore raises some question marks on the case handlers' impartiality. In their own interpretation, however, nationality does not seem to pose much difficulty. As one official explains:

I think I'm actually helping [COUNTRY] in preserving nature and fulfilling the requirements of EU law, so I don't have a feeling that I am doing something wrong for [COUNTRY], quite the opposite. In terms of dealing with the [COUNTRY] authorities, I actually believe that it is an advantage that I am a [NATIONAL], in the sense that I know their way of thinking. (Official \#13)

Finally, a particularly important and thorny aspect in the relationship with Member States is the problem of so-called "political interference," i.e., pressure exercised by Member States to avoid litigation, or delay, or sweeten the implementation of unfavorable court rulings. This issue is by no means a rare or trivial occurrence, having been mentioned by virtually all interviewees. One official even found that the main risk in their work was "political urgency being considered as more important than the continuum of the work in order to ensure equal treatment of all Member States" (Official \#17). However, case handlers view political interference as a normal part of their work in the Commission, implying an acceptance that, with some decisions, political considerations have primacy over legal ones:

So, as I see our role with the legal unit, we take reasonable steps to try and make the enforcement equal across the 27 Member States, and if there's a political reason to slow down a case, or speed up a case, that comes from the political level, and it should be discussed amongst Commissioners, and then they take a decision. (Official \#9) 


\section{Ethics and Organizational Roles in the European Commission}

The snapshots presented above highlight the fact that ethics does not materialize in the same way throughout the European Commission. It is evident that officials working in different parts of the Commission come across distinct challenges. What seems to make a difference, overall, is the type of external actors the Commission engages with, as well as officials' perception over how much power the Commission has in these relationships. Based on these elements, two organizational roles ${ }^{11}$ may be distinguished, each with its own specificity in terms of ethics.

On the one hand, officials in DG MARKT may be described as negotiators. Here, the relationship with external actors is predominantly cooperative, oriented-as demonstrated above-toward consensus-building. MARKT officials do not perceive the Commission to be in a strong position. They understand that, in order to produce EU policy, it is reliant on the information provided by, and the collaboration of, a wide variety of actors, with diverse interests and approaches. In this context, ethical challenges are connected to the inclusion of all relevant parties in policy-making, and balancing between interests with different lobbying potential.

On the other hand, DG REGIO and DG ENV come in contact with a narrower variety of external actors, since their principal interlocutors are national authorities in the Member States. Unlike the case of DG MARKT, conflict features more heavily in the relationship with these actors. Officials in DG REGIO and DG ENV may not necessarily perceive the Commission to be in a powerful position, but they are nevertheless well aware that it has teeth (i.e., imposing financial sanctions on national governments, and opening legal action against them, respectively). This knowledge is balanced against the perceived weaknesses, i.e., on the one hand, the narrow leeway to guide EU funds spending and to prevent transgressions, and, on the other, the limited technical—and political-resources to build up cases and follow them through in court. Given these circumstances, the Commission's powers are used only as a measure of last resort, the objective being rather to steer Member States into compliance in the shadow of these sanctions. For this reason, officials in DG ENV and DG REGIO may be characterized as supervisors. Despite serving different institutional functions, from an ethics perspective they appear to be quite similar, facing the same challenge to find the right balance between sticks and carrots.

This being said, the common denominator across all DGs appears to be an effort to keep one's impartiality. In MARKT, this is expressed as a concern to involve everyone relevant, while in REGIO and ENV the challenge is to avoid being too

\footnotetext{
${ }^{11}$ These should be understood as ideal types, and, given the exploratory nature of the research carried out here, the typology is tentative.
}

tough, or too soft/familiar vis-à-vis national governments, with whom contact is frequent, both formally and informally.

\section{A POLICY SOLUTION: LOCAL ETHICS CORRESPONDENTS}

The existence of these internal differences within the European Commission is something that should inform the design of organizational ethics policies. The data presented above suggests that, at least in terms of guidance, the needs of Commission employees are different. However, it was not until recently that the Commission made changes to its ethics management system, which would adapt it to organizational needs along these lines. Specifically, the appointment of ethics correspondents within each DG in 2008, which decentralized the ethics guidance function, had promising potential.

The ethics correspondents came from either the human resources, or the internal control units. The Ethics Communication was rather vague regarding their responsibilities ${ }^{12}$ - which meant that the nature of the new post was shaped only with practice and in time (Ethics official \#20). This being said, the interviews conducted with ethics correspondents revealed that their activities were clustered along two major coordinates. On the one hand, they advise, in confidentiality, on any ethics-related inquires coming from staff. On the other hand, they are in charge of managing various awareness-raising instruments, at DG level. Therefore, the ethics correspondents are ideally positioned to understand the local ethics environment, and the needs of their respective DGs, and deliver policy adaptation along these lines.

However, an analysis of administrative practice shows that this type of adaptation has not been the rule. As I have shown elsewhere, ${ }^{13}$ the communication between ethics correspondents and staff has generally been confined to subjects such as external activities (anything from teaching assignments to honorary membership in voluntary associations), publishing, and dealing with gifts and hospitality. Essentially, none of those are DG-specific, but rather represent areas where staff members are required to do some paperwork (ask for authorization, file in a declaration, etc.).

More evidence of adaptation to local conditions can be found with the second set of attributions of the ethics correspondents, i.e., the management of ethics awareness-raising. Through their network, the correspondents had access to, and

\footnotetext{
${ }^{12}$ The Ethics Communication noted only that "[e]very DG should therefore appoint an 'ethics correspondent' to serve as a focal and fist contact point for all ethics-related issues, both for the services and their staff. When dealing with queries from staff, ethics correspondents act in confidence" (Commission, 2008, p. 4).

${ }^{13}$ See Năstase (2012) for a more detailed discussion of the character of organizational communication within the Commission, on the topic of ethics.
} 
could learn from the measures and experiments implemented by their peers. This, in fact, turned out to represent a fairly rich repertoire of instruments, which included an ethics section on the DG internal website, codes of conduct/behavioral guidelines, regular internal communication on ethics issues, ethics trainings, or presentations, and other types of events dedicated to ethics (such as internal "Ethics Days," staff "away days," workshops). Essentially, ethics correspondents had enough leeway in organizing their own activity that they were free to pick and choose from this menu. This is so because the network was only loosely coordinated by DG Human Resources-several face-to-face meetings were held as the network took off, after which it continued to function mainly as an e-group (Ethics official \#20). Moreover, the coordination was mainly geared toward ensuring uniform resolution in the less straightforward cases (Ethics officials $\# 1$, \#9, \#15)—otherwise, the members used the network to share their activities, and establish best practice (Ethics officials \#15, \#18, \#20).

Some of the ethics correspondents did use their autonomy to attempt to cater for local needs. For instance, codes of conduct and ethics guidelines were introduced, with the intention to contextualize ethics to the work carried out in their respective DGs (Ethics officials \#2, \#7, \#8, \#10). Another example of local adaptation is the "Ethics Days," or "staff away days" organized in some of the DGs (Ethics officials \#4, \#6, \#11, \#14, \#16). These are rather largescale actions (over 100 participants), and generally include presentations (sometimes delivered by guest speakers) and workshops on ethics scenarios, customized to the activity of the respective DG. However, the preoccupation with local circumstances is not shared by all ethics correspondents. For instance, some of them chose not to introduce internal ethics guidelines, as they considered that the activity of their DGs was not so exceptional as to require anything in addition to what is already available from the central services (Ethics officials \#3, \# 6, \#9).

Efforts to adapt to local conditions have remained limited in the absence of a clearer message (from the coordinating center) about the need and importance of doing this. As one interviewee observed, ethics correspondents were mostly on their own (Ethics official \#17), which meant that the question of adaptation was largely down to the pro-activity, personal interest, and good judgment of individuals who served in this position.

\section{CONCLUSION}

This article explored the internal ethics environment of the European Commission, with a view to determining its specificity, and the policy responses it has triggered. The investigation aimed to offer a "bottom-up" view of ethics, as perceived and experienced by those who work within public organizations. This perspective is essential in highlighting the practical challenges of doing ethics management in a way that truly responds to organizational needs.

The most substantial part of the article was dedicated to an exploration of the activity, and the ethics challenges in three DGs (DG MARKT, DG REGIO, DG ENV). Based on interview material, it has been shown that there are differences between these parts of the Commission, in terms of how ethics is materialized in day-to-day work-life. What is more, the variation is a systematic one. Namely, it depends on the premise of the relationship between the Commission and its external stakeholders, specifically on the mix between cooperation and conflict. Along with this, the power of the Commission (as perceived by officials themselves) varies, which is what seems to give rise to the distinct ethical challenges identified above.

The article ended by discussing a policy solution which had the potential to address the internal variation described above. Namely, in 2008 a network of ethics correspondents was created within the Commission. The role of these correspondents was not entirely clear, and it is reasonable to assume that the measure was simply meant to add more vigor to awareness-raising efforts. This meant that, in practice, the ethics correspondents were afforded enough flexibility to define their own activity, a fact which has led some (but not all) to introduce measures which catered for the specificity of their respective DGs.

By studying ethical questions in highly contextualized work settings, this article has highlighted an important challenge in the practice of ethics management, which is not often recognized, or discussed. Namely, organizations must strike a delicate balance between, on the one hand, ensuring that all employees abide by uniform ethical standards, and, on the other, allowing enough flexibility to cater for differences in the internal work environment. The European Commission might be an extreme case in this regard, but arguably its example does have general value for organizations above a certain level of complexity. In the Commission, the need to adapt ethics management (particularly ethics guidance) to internal variations has not gone unnoticed. The fact that such adaptation has not been systematic illustrates two important aspects. First, understanding and catering for specific contexts and subtle variations is simply not easy, quick, or cheap. Second, given that resources are always limited, the objective of uniform ethical standards (and especially preventing transgressions) does seem to take priority. After all, in the public's perception the Commission is just one organization, and, if we accept that increasing public trust is a fundamental objective in any ethics management exercise, presenting a united front appears more important.

\section{REFERENCES}

Abélès, M., Bellier, I., \& McDonald, M. (1993). Approche anthropologique de la Commission Européenne. Brussels [unpublished]. 
Behnke, N. (2002). A Nolan committee for the German ethics infrastructure? European Journal of Political Research, 41, 675-708.

Bossaert, D., \& Demmke, C. (2005). Main challenges in the field of ethics and integrity in the EU member states. Maastricht: European Institute of Public Administration.

Bowman, J. S. (Ed.). (1991). Ethical frontiers in public management: Seeking new strategies for resolving ethical dilemmas (1st ed.). San Francisco, CA: Jossey-Bass.

Christiansen, T. (1997). Tensions of European governance: Politicized bureaucracy and multiple accountability in the European Commission. Journal of European Public Policy, 4(1), 73-90.

Cini, M. (1996). The European Commission: Leadership, organization and culture in the EU administration. Manchester, New York: Manchester University Press.

Cini, M. (1997). Administrative culture in the European Commission: The cases of competition and environment. In N. Nugent (Ed.), At the heart of the union: Studies of the European Commission (pp. 71-88). Basingstoke: Macmillan.

Cini, M. (2004). The reform of the European Commission: An ethical perspective. Public Policy and Administration, 19(3), 42-54.

Cini, M. (2007). From integration to integrity: Administrative ethics and reform in the European Commission. Manchester: Manchester University Press.

Cini, M. (2008). European Commission reform and the origins of the European transparency initiative. Journal of European Public Policy, 15, $743-760$.

Cini, M. (2010). Éthique Et Réforme Administrative De La Commission Européenne. Revue Française D'administration Publique, 133, 45-60.

Cini, M. (2013). Institutional change and ethics management in the EU's college of commissioners. The British Journal of Politics \& International Relations. Advance Online Publication. Retrieved February 1, 2013. doi:10.1111/1467-856X.12008.

Commission of the European Communities. (2007). Revision of the internal control standards and underlying framework: Strengthening control effectiveness (SEC(2007)1341). Brussels: Author.

Commission of the European Communities. (2008). Communication from Vice-President Kallas to the Commission on enhancing the environment for professional ethics in the Commission. SEC(2008) 301. Brussels: Author.

Coombes, D. (1970). Bureaucracy and politics in the European Union - A portrait of the Commission of the E.C.C. London: George Allen \& Unwin.

Cooper, T. L. (1998). The responsible administrator: An approach to ethics for the administrative role (4th ed.). San Francisco, CA: Jossey-Bass.

Cram, L. (1994). The European Commission as a multi-organization: Social policy and IT policy in the EU. Journal of European Public Policy, 1(3), 195.

De Graaf, G. (2011). The loyalties of top public administrators. Journal of Public Administration Research and Theory, 21(2), 285-306.

Denhardt, K. G. (1988). The ethics of public service: Resolving moral dilemmas in public organizations. New York: Greenwood Press.

Dercks, L. (2001). The European Commission's business ethics: A critique of proposed reforms. Business Ethics: A European Review, 10(4), 346-359.

Ford, R. C., \& Richardson, W. D. (1994). Ethical decision making: A review of the empirical literature. Journal of Business Ethics, 13, 205-221.

Frederickson, G. H., \& Walling, J. D. (2001). Research and knowledge in administrative ethics. In T. L. Cooper (Ed.), Handbook of administrative ethics (pp. 37-58, 2nd ed.). New York: Marcel Dekker.

Giusta, P. (2006). Ethics matters: Practical micro-ethics for civil servants of the European Union. Luxembourg: Office for Official Publications of the European Communities.

Hine, D., \& McMahon, R. (2004). Ethics management, cultural change, and the ambiguities of European Commission reform. Oxford: Department of Politics and International Relations, University of Oxford. Retrieved January 22, 2008, from http://government.politics.ox.ac.uk/Projects/ Papers/Hine-McMahon_Ethics_Management.pdf
Hooghe, L. (2001). The European Commission and the integration of Europe: Images of governance. Cambridge: Cambridge University Press. Hooghe, L. (2012). Images of Europe: How Commission officials conceive their institution's role. Journal of Common Market Studies, 50(1), 87-111.

Judge, D., \& Earnshaw, D. (2002, July 1). The European Parliament and the Commission crisis: A new assertiveness? Governance, 15(3), 345-374.

Kohlberg, L. (1969). Stage and sequence. The cognitive developmental approach to socialization. In D. A. Goslin (Ed.), Handbook of socialization theory (pp. 347-480). Chicago: Rand McNally.

Kohlberg, L. (1981). The philosophy of moral development: Moral stages and the idea of justice. San Francisco, CA: Harper and Row.

Laverty, E. B. (1989). The ethical context of administrative decisions: A framework for analysis. Public Administration Quarterly, 13(3), 375-387.

Loe, T. W., Ferrell, L., \& Mansfield, P. (2000). A review of empirical studies assessing ethical decision-making in business. Journal of Business Ethics, $25,185-204$.

Lupson, J., \& Partington, D. (2011). Individual civil servants' conceptions of accountability. Public Management Review, 13(7), 895-918.

MacMullen, A. (1999, October 1). Political responsibility for the administration of Europe: The commission's resignation March 1999. Parliamentary Affairs, 52(4), 703-718.

Menzel, D. C. (2001). Ethics management in public organizations: What, why and how? In T. L. Cooper (Ed.), Handbook of administrative ethics (pp. 355-366, 2nd ed.). New York: Marcel Dekker.

Menzel, D. C. (2005). Research on ethics and integrity in governance. Public Integrity, 7(2), 147-168.

Morgan, D. F., \& Kaas, H. D. (1993). The American odyssey of the career public service: The ethical crisis of role reversal. In H. G. Frederickson (Ed.), Ethics and public administration (pp. 177-190). Armonk, NY M.E. Sharpe.

Năstase, A. (2012). Managing ethics in the European Commission services. Public Management Review, 15(1), 63-81.

Nugent, N. (1997). At the heart of the Union: Studies of the European Commission. Basingstoke: Macmillan.

Nugent, N. (2001). The European Commission. Basingstoke: Palgrave.

OECD. (1996). Ethics in the public service: Current issues and practice. Public Management Occasional Papers, No 14. Paris: OECD, Public Management Service.

OECD. (2000). Trust in government: Ethics measures in OECD countries. Paris: Author.

OECD. (2009). Towards a sound integrity framework: Instruments, processes, structures, and conditions for implementation. Paris: Author.

O'Fallon, M. J., \& Butterfield, K. D. (2005). A review of the empirical ethical decision-making literature: 1996-2003. Journal of Business Ethics, $59,375-413$

Page, E. C. (1997). People who run Europe. Oxford: Clarendon Press.

Palidauskaite, J. (2005). Codes of ethics in transitional democracies. Public Integrity, 8(1), 34-48.

Palidauskaite, J., Pevkur, A., \& Reinholde, I. (2010). A comparative approach to civil service ethics in Estonia, Latvia and Lithuania. Journal of Baltic Studies, 41(1), 45-71.

Rest, J. R. (1986). Moral development: Advances in research and theory. New York: Praeger.

Sbargia, A. M. (Ed.). (1992). Euro-politics. Washington, DC: Brookings.

Scharpf, F. W. (1988). The joint-decision trap: Lessons from German federalism and European integration. Public Administration, 66, 239-278.

Schön-Quinlivan, E. (2008). Implementing organizational change - the case of the Kinnock reforms. Journal of European Public Policy, 15(5), $726-742$.

Shore, C. (2000). Building Europe: The cultural politics of European integration. London: Routledge.

Smith, R. W. (2003). Corporate ethics officers and government ethics administrators. Administration \& Society, 34(1), 632-652. 
Smith, R. W. (2004). A comparison of the ethics infrastructure in China and the United States. Public Integrity, 6(4), 299-318.

Spence, D. (2006). The president, the college and the cabinets. In D. Spence \& G. Edwards (Eds.), The European Commission (pp. 25-74, 3rd ed.). London: John Harper.

Spence, D., \& Stevens, A. (2006). Staff and personnel policy in the Commission. In D. Spence \& G. Edwards (Eds.), The European Commission (pp. 173-208, 3rd ed.). London: John Harper.

Stevens, A., \& Stevens, H. (2001). Brussels bureaucrats?: The administration of the European Union. New York: Palgrave.

Wallace, W. (1983). Less than a federation, more than a regime: The community as a political system. In W. Wallace, H. Wallace, \& C. Webb (Eds.), Policy making in the European community (pp. 403-436, 2nd ed.). New York: Wiley.
West, J. P., \& Berman, E. M. (2003). Audit committees and accountability in local government: A national survey. International Journal of Public Administration, 26, 329-362.

West, J. P., \& Berman, E. M. (2004). Ethics training in U.S. cities: Content, pedagogy, and impact. Public Integrity, 6(3), 189-206.

Wittmer, D. P. (2001). Ethical decision-making. In T. L. Cooper (Ed.), Handbook of administrative ethics (pp. 481-508, 2nd ed.). New York: Marcel Dekker.

Wittmer, D. P. (2005). Developing a behavioural model for ethical decision making in organizations: Conceptual and empirical research. In G. H Frederickson \& R. K. Ghere (Eds.), Ethics in public management (pp. 49-69). Armonk, NY: M.E. Sharpe. 